\title{
Competitiveness of the Oil Market and Profitability of the Oil Industry in Federation of Bosnia and Herzegovina
}

\author{
Najla Mujić, Adisa Omerbegović Arapović \& Ermin Cero \\ International Burch University, Sarajevo, BOSNIA AND HERZEGOVINA \\ Faculty of Economics and Social Sciences
}

Received 24 July 2019 • Revised 28 August 2019 • Accepted 29 August 2019

\begin{abstract}
This research examines different hypotheses that explain generic profitability within the framework of the hypothesis of efficiency, representing its main contribution to the use of direct measurement of efficiency through profitability and market competition. This measurement is achieved using pioneering techniques using a model in the scientific work Profitability, market structure and efficiency by M. Gumbau and J. Maudos (2000). Evidence obtained enables us not to reject the hypothesis about the profitability of oil producers in $\mathrm{B} \& \mathrm{H}$, to determine whether the concentration positively affects profitability, and further, the results in most cases, enabled us to reject a clean hypothesis of efficiency since, although efficiency contributes positively to explaining the differences in profitability, the market share, which encompasses the effect of market power, also has a positive impact on it. So, from results obtained we do not reject the hypothesis of profitability so that we find positive relationship between profitability and the market share of Oil industry in Federation of Bosnia and Herzegovina.
\end{abstract}

Keywords: profitability, market share, market structure, competitiveness.

\section{Introduction}

This study investigates degree of competitiveness of oil industry and tests whether the industry exhibits features of oligopolistic market structure by studying profit margins of oil companies compared to the more competitive industries in the state.

In the field of industrial organization, the analysis of the relationship between profitability and market structure has given rise to abundant literature of both theoretical and empirical nature.

There are two alternative hypotheses that have been put forward to explain the positive correlation usually found between performance and market share (concentration). First hypothesis, the so called traditional hypothesis of collusion, or structure-conduct-performance paradigm (Bain, 1951), affirms that concentration favors the adoption of collusive agreements, thus leading to the obtaining of monopoly rents. Muller (1977) in his study The persistence of profits above the norm stated that high profits are associated with high concentration and entry barriers.

Secondly, the hypothesis of efficiency (Demsetz, 1973, 1974) posits that concentration of the market is the result of the greater efficiency of some firms, which consequently gain in

(C) Authors. Terms and conditions of Creative Commons Attribution 4.0 International (CC BY 4.0) apply. Correspondence: Najla Mujić, Faculty of Economics and Social Sciences, International Burch University, Sarajevo, BOSNIA AND HERZEGOVINA. E-mail: najla.mujic@stu.ibu.edu.ba. 
market share and are more profitable. In this case, the positive correlation between profitability and concentration is spurious, efficiency being the variable that genuinely explains profitability.

Usually, the way of testing both hypotheses has been to introduce concentration and market share as explanatory variables of profitability, on the assumption that market share will reflect the effect of efficiency. In this case, if the market share positively affects profitability, and concentration is not significant, the hypothesis of efficiency is not rejected (Gumbau \& Maudos, 2000: 3).

Gumbau and Maudas (2000) agree that differences in efficiency are identified with differences in market share, because increasing returns to scale are being assumed. Thus, large sized firms produce with lower unit costs thus obtaining higher levels of profitability.

\subsection{Background of the study}

We test the relationship between profitability and market structure following the methodology of Gumbau and Maudos (2000) which explains the relationship between profitability and market structure, and the interpretation of the relationship between profitability and market share in Spanish industry (Ibid., 2000: 5-13).

Sousa (2015) states that studies on market structure and firm performance are of four kinds (four empirical studies): Structure-Conduct-Performance (SCP), Relative Market Power (RMP), Efficient-Structure Hypothesis (ESS) and X-efficiency version (ESX), although the SCP and RMP dominate (Sousa, 2015: 6).

The SCP theory is based on concentrated markets taking into account that prices in those markets lead to discouraging consumption (Berger, 1995). The RMP focuses on companies' profitability when companies have large market share imposed in the market due to power engaged in business and pricing (Berger, 1995).

Normally, the market power is accomplished by factors that companies use such as the level of advertising, the size of the firm and the high firm growth. ESX and ESS are both based in explaining that lower costs leading to higher profits. The difference is that ESX focuses on how management and the consequences of a good or bad administration combined with production technology can lead to a better financial performance of firms.

The theory of industrial organization provides classical models of oligopolistic behavior as a framework for analyzing the determinants of profitability. Firms are considered to compete in the market for a good, maximizing their profits. Each of them, in turn, operates in an industry in which the strategies of the other firms can interact with its own.

This analysis is done for the purpose of portraying Oil industry's profits, as presumably a monopolistic industry, in comparison to profits from organizations of more competitive market. Also, very often in media it has been stated that prices of Oil in our country do not go down compared to price movements in the global oil markets.

We follow the premise that unlike in competitive markets monopolies limit production in order to keep prices and profits high. Their market power usually makes economy less productive. High prices in monopolistic market also go in the purchasing power of wages. In the study by IMF evidence for this theory was provided, where the markups over marginal cost charged by over 900,000 firms in 27 countries was studied. They realized that markups rose for $8 \%$ mostly in the US and by a smaller amount in Europe. Also IMF states that in most places, small share of firms are responsible for rising markups (Economist, 2019: 61). 


\subsection{The Oil industry in Federation of Bosnia and Herzegovina}

In the Study of energy sector in B\&H (Granić et al., 2008) the current state of the oil sector and its detailed analysis is presented. The study concluded that the market for petroleum products in $\mathrm{B} \& \mathrm{H}$ is almost completely dependent on imports, which was one of the most important aspects for analysis. According to the available data, the consumption of derivatives in Bosnia and Herzegovina ranged from about 800,000 tons in 2000 to 1.3 million tons in 2005. Imports of petroleum products were mostly made in Croatia, Serbia, Montenegro and Hungary. According to the structure of final consumption, the largest share in the final consumption of petroleum products is occupied by traffic (almost 70\%), followed by industry with 12\%, households with 10\%, agriculture with $8 \%$ and service sector with only $2 \%$. The structure of consumers of certain types of derivatives was determined on the basis of a survey carried out in both Entities and Brčko District and on the basis of data collected from competent institutions. The survey covered 4,000 households and 739 companies from the industry and services sector.

In Bosnia and Herzegovina, there are over 800 gas stations, many of which were built after the adoption of the Law on Private Economy in Bosnia and Herzegovina in 1990. In terms of competitiveness, this can be considered somewhat acceptable, but in terms of economy, it is certainly irrational investments, and now the operation of a certain number of petrol stations takes place at the profitability limit, and some of them are closed.

It is important to note that in Bosnia and Herzegovina exists the so-called "free forming of price", i.e. price determines the market. Compared to EU countries, retail prices of derivatives are significantly lower in $\mathrm{B} \& \mathrm{H}$, but this is solely due to lower excise duties and taxes. If the net prices are compared, then they are somewhat higher in B\&H than in the EU countries. Special reference was made to the legal regulations related to the quality of liquid petroleum fuels in the European Union, the Republic of Croatia and Bosnia and Herzegovina. The Republic of Croatia has largely harmonized its laws with the EU directives, and for a certain period of time, it is possible to produce and sell certain quantities of derivatives that are not in line with EU standards. B\&H has set standards for the quality of liquid petroleum fuels that have been harmonized with EU standards, whereby fuels produced in B\&H over a certain period of time can deviate quality from standards prescribed in the EU.

The decision on the free formation of prices of motor gasoline, diesel fuel and fuel oil (Official Gazette FB\&H, 52/oo) of the prices of petroleum products are formed freely, with the customs, special tax on petroleum products (excise), road fees tolls / tolls) and value added tax are calculated in accordance with the relevant regulations.

All other information, charts and researches on Oil sector in B\&H are available in ESSBIH Treći projekat obnove, Studij energetskog sektora BIH, konačni izveštaj (Granić et al., 2008) [Third project of renovation, Study of energy sector in B\&H, final report, 2008].

\subsection{Research objective}

In the first part of the paper, the retail oil derivatives industry will be analyzed to provide some general information and trend analysis in comparison to the competitive industry of Logistics services in Federation of Bosnia and Herzegovina. In the second part of the paper we test the hypothesis of positive relationship between firm profitability and the structure of the market in which the firms operate.

This study aims to provide a detailed insight into the competitiveness and profitability of the Oil market industry in Federation of Bosnia and Herzegovina. questions:

The main objective of this research paper is to answer the following research 
- What is the market structure in which oil firms operate?

- How profitability of Oil sector in B\&H behaves over time in relation to Logistics service sector?

- What is the relationship between main financial variables of both oil companies and logistics service companies, such as gross profit margins and the market size of the company?

Generically, two alternative hypotheses have been put forward to explain positive correlation usually found between performance and concentration, i.e. market share. Traditional hypothesis of collusion or structure-conduct performance paradigm (Bain, 1951) leading to the obtaining of monopoly rents. The hypothesis of efficiency (Demsetz, 1973) posits that concentration of the market is the result of the greater efficiency. Shepard (1982) argues that firms may have market power when they enjoy high market shares.

One solution to the problem of the degree of confidence in the use of market share as a proxy for efficiency is to assume different level of efficiency in the market.

In recent years several studies have been made to test the various hypothesis explaining the relationship between profitability and the market structure:

- The main methodological contribution of Schmalensee (1987) is the analysis of the implications of relaxing the assumption of constant returns to scale,

- Mazon (1993) using data from the Central Balance Sheet of the Bank of Spain also obtains the results that support hypothesis which states that there is positive relationship between market structure and efficiency of the market, using market share as a proxy of efficiency.

We follow the approach by Mercedes Gumbau and Joaquín Maudos of testing the relationship between profitability, market share and efficiency. We do not measure efficiency directly through production frontier techniques, but we measure by various assumptions of efficiency (Gumbau \& Maudos, 2000).

\subsection{Significance of the study}

This study brings closer overview of the Oil industry and Logistics service industry in Federation of Bosnia and Herzegovina. Data obtained through Business Intelligence System will give us closer overview about the market in which both industries are competing, what is their degree of competitiveness, how profitability behaves over time for each of the industry. Also this article will be comparing profits of Oil industry with Logistics service industry through five year period, to see if the Oil industry is annoying the profits above the norm.

Also this study will offer new evidence on the relationship between profitability and the market structure and the interpretation of the relationship between profitability and the market share in the B\&H Oil industry.

By testing the relationship between profitability, market share and efficiency the study's main contribution is to accept the hypothesis which states that there is positive relationship between profitability and market structure.

Also contributions of this study is to offer statistical and real data about the Oil industry in $\mathrm{B} \& \mathrm{H}$ which directly affects the economic activity and standard of lives in the country, as uncompetitive markets result in dead weigh losses, or loss of welfare for the consumers. 


\section{Research methodology}

The main hypothesis tested is:

Ho: There is a positive relationship between firm profitability and the structure of the market in which the firm operates.

Control group of the research is Logistics service industry which is operating in the highly competitive market comparing to oil firms.

Traditionally, the most usual way of testing hypothesis has been to introduce concentration and market share as explanatory variables of profitability, on the assumption that market share will reflect the effect of efficiency. In this case, if the market share positively affects profitability, and concentration is not significant, the hypothesis of efficiency is not rejected. Normally, differences in efficiency are identified with differences in market share, because increasing returns to scale are being assumed.

The market structure model measures: Concentration, Market Share and the logarithm of the turnover or number of employees (both scale variables). Concentration is computed by Herfindahl-Hirschman Index known as HH Index or HHI and the Market Share (MS) as a percentage (share) of the volume of turnover in each firm in the total of the sector where the firm belongs.

In order to answer our first research question the following will be used: (1) Concentration ratio, and (2) Harfindahl-Hirschman index HHI.

Industrial concentration reflects the number and size of an enterprise in a given market share. Harfindahl-Hirschman index is measured by the sum of the squares of the market shares of individual enterprises in the industry. This index can have a value of up to 10,000.

Calculation of HHI will be calculated from formula:

$H H I=s_{1}{ }^{2}+s_{2}{ }^{2}+s_{3}{ }^{2} \ldots+s_{n}{ }^{2}-$ where $s_{n}$ is the market share percentage of firm $n$ expressed as a whole number, not a decimal.

Market share is calculated as its sales measured as a percentage of an industry's total revenues. A company's market share is determined by dividing its total sales or revenues by the industry's total sales over a fiscal period.

In order to study how profitability of Oil sector behaves over time compared to Logistics service sector, we will observe and compare the profitability curve for Oil sector and Logistics services sector in Federation of Bosnia and Herzegovina over the period 2014-2019. In this research five year profitability of both sectors will be compared and graphically represented to have a clear image of observed data.

For analysis of the profitability we will follow methodology and use the model from Mercedes Gumbau and Joaquín Maudos in their article (Gumbau \& Maudos, 2000).

The theory of industrial organization provides classical models of oligopolistic behavior as a framework for analyzing the determinants of profitability. Firms are considered to compete in the market for a good, maximizing their profits. Each of them, in turn, operates in an industry in which the strategies of the other firms can interact with its own.

According to the pure efficient structure hypothesis the most efficient firms will have lower costs and therefore higher profits, and in this way they gain market share, consequently increasing concentration. Nevertheless, although it is efficiency that leads to a higher market share and concentration, these latter should not bear any relationship to profitability once efficiency has been introduced into the estimation. Thus, according to the hypothesis of efficient structure, the expected signs of the relationship are as follows: $\mathrm{EF}>0, \mathrm{CR}=0, \mathrm{MS}=0$. 
Observe that the efficient structure hypothesis further requires that efficiency leads to a higher market share and greater market concentration. That is to say, that an additional necessary condition for sustaining this hypothesis is that efficiency be an explanatory variable of market share and concentration, and that they be positively correlated.

The introduction only of market share, concentration and efficiency as explanatory variables of profitability may give rise to an omitted-variable bias given the possible existence of other variables that explain profitability. These variables are specific to firms or to the markets in which they operate.

It is usual in this type of models to assume that there are constant returns to scale, so that empirically it is possible to proxy the price cost margin by the value of production minus variable costs divided by the value of production. However, as pointed out by Schmalensee (1989) this specification omits capital costs. The traditional solution to this problem is to introduce capital intensity as a further explanatory variable (KI).

Other control variables are also included in the regression so as not to ignore the differences occurring among firms and the sectors in which they work. For the differences among firms, we introduce variables that quantify the entrance barriers associated with advertising intensity (ADV) and the innovation effort made by the firm (R\&D), while for the differences among markets we introduce the variables that control for the demand conditions of the market in which the firm operates (stable, expanding or receding market) (STA, EXP, REC) and the possible existence of entrance barriers associated with the minimum efficient size of firms (NCOMP1, NCOMP2).

The advertising effort made by a firm is considered to be an entrance barrier, or production cost to be incurred by a firm that aims to enter an industry but not borne by the firms already installed. It is understood that a higher relative advertising expenditure implies greater differentiation of the product manufactured, and that inelasticity of the cross-price demand curve faced by the firm is greater in this case, so the firm may obtain higher profits per unit of production.

We also control for the effects exercised by economic opportunities on the profitability of firms. It is to be expected that those firms that operate in expanding or stable markets will have more economic opportunities than those in markets with receding demand, and therefore, that the profits of the former will be more favored than those of the latter.

Finally, it is well known that the presence of barriers to the entrance of new competitors reduces the chances of survival of a firm in the market. For this reason, it is necessary to consider the possible effect of these entrance barriers on the profits of firms.

Therefore, the equation to be estimated is as follows:

$$
\begin{aligned}
& P C M i=\mathrm{a}_{O}+\mathrm{a}_{1} M S i+\mathrm{a}_{2} C R j+\mathrm{a}_{3} E F i+\mathrm{a}_{4} K I i^{+} \mathrm{a}_{5} A D V i+\mathrm{a}_{6} R+D i^{+} \\
& \text {a } 7 \mathrm{STAi}^{+} \text {a } 8 R E C i+\text { a }{ }_{9} \mathrm{NCOMP}_{1 i} i^{+} \text {a }{ }_{10} \mathrm{NCOMP}_{2 i} i_{\mathrm{e}} I \\
& \text { Equation } 1
\end{aligned}
$$

Where:

1. Price-cost margin (PCM): variable will be calculated by net profit divided by total sum of sales of the organization.

2. Efficiency (EF): following variables will be used through authors assumptions of industrial efficiency:

- $50 \%$ or 0.5 variable of efficiency is low efficient market,

- $75 \%$ or 0.75 variable of efficiency is moderate efficient market,

- $95 \%$ or 0.9 variable of efficiency is highly efficient market. 
3. Capital intensity ratio (KI) of a company is a measure of the amount of capital needed per dollar of revenue. It is calculated by dividing total assets of a company by its sales. It is reciprocal of total asset turnover ratio.

4. Concentration (CR) - Harfindahl-Hirschman index is measured by the sum of the squares of the market shares of individual enterprises in the industry. This index can have a value of up to 10,000.

5. Market share (MS) - The sales of the firm as a percentage of the main market in which it operates.

6. Conditions of the market in which the firm operates (stable, expanding or receding market) (STA, EXP, REC).

7. Research and Development (R\&D) - instrumental variable will be used by using ratio of proxy $\mathrm{R} \& \mathrm{D}$ expenditure/sales of the firm.

8. The existence of barriers of entry - NCOMP1 - to denote that the firm considers itself to have more than 25 competitors in its sector with a significant market share, and NCOMP2 - 10 of fewer competitors with significant market share.

9. Advertising effort made by each firm (ADV) - instrumental variable will be used by using ratio of proxy of advertising costs divided by sales.

3. Data analysis and interpretation

3.1 The market structure of Oil industry and Logistics service industry

In order to study the market structure in which oil firms operate the following will be used: (1) Concentration ratio, and (2) Harfindahl-Hirschman index HHI.

Industrial concentration reflects the number and size of an enterprise in a given market share. Harfindahl-Hirschman index is measured by the sum of the squares of the market shares of individual enterprises in the industry. This index can have a value of up to 10,000.

Calculation of HHI will be calculated from formula:

$H H I=s_{1}{ }^{2}+s_{2}{ }^{2}+s_{3}{ }^{2} \ldots+s_{n}{ }^{2}-$ where $s_{n}$ is the market share percentage of firm $n$ expressed as a whole number, not a decimal.

A company's market share is determined by dividing its total sales or revenues by the industry's total sales over a fiscal period.

For better analysis of competitiveness in individual markets, it can be use the following division of market structures using Harfindahl-Hirschman's index.

Table 1 (Begović et al., 2002: 35)

\begin{tabular}{|l|l|}
\hline Value HHI & The degree of concentration \\
\hline HHI $<1 O O O$ & Unconcentrated (Low-concentrated) \\
\hline $\mathbf{1 O O O}<$ HHI $<\mathbf{1 8 O O}$ & Medium concentrated supply \\
\hline $\mathbf{1 8 O O}<\boldsymbol{H H I}<\mathbf{2 6 O O}$ & Highly concentrated supply \\
\hline $\mathbf{2 6 O O}<$ HHI $<\mathbf{1 O O O}$ & Very highly concentrated supply \\
\hline HHI $=10 O O$ & Monopoly concentrated supply \\
\hline
\end{tabular}

The significance of the index is reflected in the fact that although it respects the individual market the participation of all companies in the branch, he nevertheless responds in particular to the presence of the company with a large market share, which significantly increase its value (Lipczynski \& Wilson, 2001: 110). This index, theoretically, may have a value between 0 to 10,000. In the case of atomized supply, when there is a huge number of manufacturers and when the offer of each of them tends to $\mathrm{o}$ and the index value tends to 0 . At the monopoly value 
the index is 10,00o, because the offer of the monopoly company is equal to the whole offer branches (Begović et al., 2002: 33).

We have analyzed the top 10 firms with the highest total sales in the industry code 46.71 Wholesale of fuels for the period 2014-2019.

$$
\begin{gathered}
H H I_{2014}=14^{2}+14^{2}+11^{2}+2^{2}+2^{2}+1^{2}+1^{2}+0^{2}+0^{2}+0^{2}=523 \\
H H I_{2015}=30^{2}+17^{2}+13^{2}+10^{2}+5^{2}+5^{2}+2^{2}+2^{2}+2^{2}+2^{2}=1524 \\
H H I_{2016}=30^{2}+16^{2}+13^{2}+10^{2}+5^{2}+5^{2}+3^{2}+2^{2}+1^{2}+1^{2}=1490 \\
H H I_{2017}=30^{2}+15^{2}+12^{2}+11^{2}+6^{2}+4^{2}+4^{2}+3^{2}+2^{2}+1^{2}=1472 \\
H H I_{2018}=34^{2}+15^{2}+15^{2}+10^{2}+4^{2}+4^{2}+2^{2}+2^{2}+2^{2}+1^{2}=1751
\end{gathered}
$$

The significance of the index is reflected in the fact that although it respects the individual market participation of all companies in the branch, he nevertheless responds specifically to the presence of the company with a large market share, which significantly increases its value (Lipczynski \& Wilson, 2001: 110).

Even though values of HHI calculated fit into Medium concentrated type of market, more important observation is the fact that just up to ten firms in the whole industry have percentage of market share above $1 \%$, and one has the largest share in industry of $30-40 \%$ market share which is more than double of every other firm in the industry.

So here we can conclude even if the market ostensibly looks sort-of competitive, the market share of each firm calculated shows us that there is one leading company in the industry over the observed period of time and all other things constant, market share is continuously rising for this particular firm.

3.2 Behavior of profitability of Oil sector compared to Logistics service sector 20142019

How profitability of Oil sector in $B \& H$ behaves over time in relation to Logistics service industry is answered and described below.

We have compared the total revenues of Oil sector in Industry codes 46.71 Wholesale of fuels and 47.30 Retail sale of motor fuels and total revenues of Logistics service sector in Industry codes 53.10 Postal and courier services and 53.20 Additional activity of other postal and courier services over the period 2014-2019.

Table 2. Profitability of Oil sector and Logistics sector over period

\begin{tabular}{|c|c|c|}
\hline Period & Net profit - Oil sector & $\begin{array}{c}\text { Net profit - Logistics } \\
\text { service sector }\end{array}$ \\
\hline $\mathbf{2 0 1 4}$ & $55,716,756$ & $5,824,053$ \\
\hline $\mathbf{2 0 1 5}$ & $75,613,612$ & $4,367,532$ \\
\hline $\mathbf{2 0 1 6}$ & $97,190,404$ & $4,952,778$ \\
\hline $\mathbf{2 0 1 7}$ & $107,264,045$ & $3,023,051$ \\
\hline $\mathbf{2 0 1 8}$ & $102,135,058$ & $1,835,290$ \\
\hline
\end{tabular}




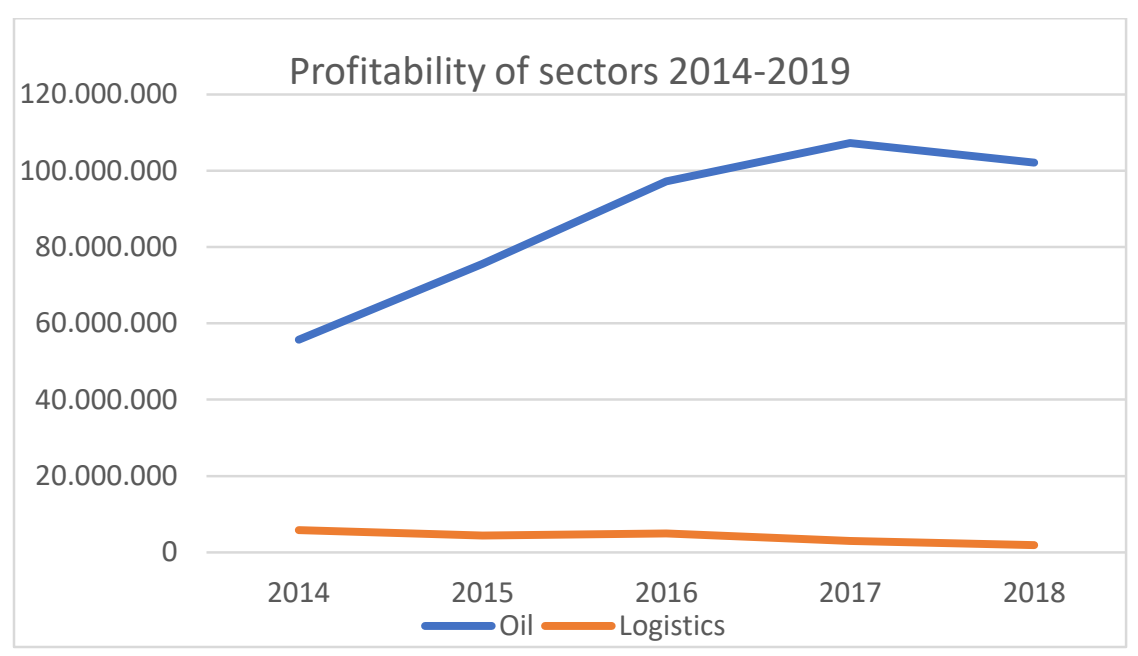

Figure 1. Comparing differences in profits of two sectors

In comparing the differences in profitability of two sectors we used simple comparison of Net profits over the period for both Oil sector and Logistics service sectors to have the clear image of differences in profitability.

Using this simple descriptive chart, we have clear image of huge differences in profitability of Oil sector over the Logistics service sector. Also the Oil sector profitability multiplies two times from 2014 until 2018 (from 55,716,765 KM in 2014 to 102,135,058 KM in 2018), where we can see the curve facing upwards.

On the other hand we see the decreasing trend in profitability of Logistics service sectors where profitability of industry in 2014 was 5,824,052 KM and multiple times lower in 2018 where the profitability of the industry was just $1,835,290 \mathrm{KM}$

Based on the data, there is a huge gap between two curves which represent the profitability of Oil sector over the Logistics service sector.

Based on this research and observation, we can state that Oil industry in FB\&H is surely enjoying the profits above the norm comparing to other industries in country.

3.3 The relationship between main financial variables, gross profit margins and the market size of the company

As explained in methodology section the above stated relationship will be studied estimating the following equation using the Linear regression model through EViews statistical program:

This will be answered through the equation to be estimated is as follows:

$$
\begin{gathered}
P C M i=\mathrm{a}_{O}+\mathrm{a}_{1} M S i+\mathrm{a}_{2} C R j^{+} \mathrm{a}_{3} E F i^{+} \mathrm{a}_{4} K I i^{+} \mathrm{a}_{5} A D V i+\mathrm{a}_{6} R+D i^{+} \\
\text {a } 7 S T A i^{+} \text {a } 8 R E C i+a_{9} N C O M P_{1 i}+{ }_{10} N C O M P_{2 i}+\mathrm{e} i
\end{gathered}
$$

Where:

1. Price-cost margin (PCM): variable will be calculated by net profit divided by total sum of sales of the organization.

2. Efficiency (EF) following variables will be used through authors assumptions of industrial efficiency:

- 50\% or 0.5 variable of efficiency is low efficient market, 
- $75 \%$ or 0.75 variable of efficiency is moderate efficient market,

- 95\% or 0.9 variable of efficiency is highly efficient market.

3. Capital intensity ratio (KI) of a company is a measure of the amount of capital needed per dollar of revenue. It is calculated by dividing total assets of a company by its sales. It is reciprocal of total asset turnover ratio.

4. Concentration (CR) - Harfindahl-Hirschman index is measured by the sum of the squares of the market shares of individual enterprises in the industry. This index can have a value of up to 10,000 .

5. Market share (MS) - The sales of the firm as a percentage of the main market in which it operates.

6. Conditions of the market in which the firm operates (stable, expanding or receding market) (STA, EXP, REC)(0.1-1).

7. Research and Development (R\&D) - instrumental variable will be used by using ratio of proxy R\&D expentidure/sales of the firm.

8. The existance of barriers of entry - NCOMP1 - to denote that the firm considers itseflt to have mora than 25 competitors in its sector with a significant market share, and NCOMP2 - 10 of fewer competitors with significant market share.

9. Advertising effort made by each firm (ADV) - instrumental variable will be used by using ratio of proxy of advertising costs divided by sales.

Following the described model below are the results for Oil industry sector considering $50 \%$ efficiency of industry, $75 \%$ efficiency of industry and $95 \%$ efficiency of industry:

- Considering that Oil industry is 50\% efficient, through EViews statistical program we have obtained following results:

\begin{tabular}{|c|c|c|c|c|c|}
\hline \multicolumn{6}{|c|}{ Included observations: 597} \\
\hline Variable & Coefficient & \multicolumn{2}{|c|}{ Std. Error } & t-Statistics & Prob. \\
\hline NCOMP & -204.0633 & \multicolumn{2}{|c|}{1538.247} & -0.132660 & 0.8945 \\
\hline$\overline{E F}$ & 81.69752 & \multicolumn{2}{|c|}{8757.471} & 0.009329 & 0.9926 \\
\hline EX & -57.23547 & \multicolumn{2}{|c|}{4378.742} & -0.013071 & 0.9896 \\
\hline $\mathrm{ADV}$ & -0.003377 & \multicolumn{2}{|c|}{0.062715} & -0.053842 & 0.9571 \\
\hline CR & -8.951699 & \multicolumn{2}{|c|}{167.6666} & -0.053390 & 0.9574 \\
\hline KI & 0.000176 & \multicolumn{2}{|c|}{0.003458} & 0.050848 & 0.9595 \\
\hline MS & 136.3312 & \multicolumn{2}{|c|}{$745 \cdot 3170$} & 0.182917 & 0.8549 \\
\hline $\mathrm{RD}$ & 0.036914 & \multicolumn{2}{|c|}{0.325572} & 0.113383 & 0.9098 \\
\hline \multicolumn{2}{|c|}{$\begin{array}{l}\text { R-sqaured } \\
0.000163\end{array}$} & \multicolumn{4}{|c|}{\begin{tabular}{|l} 
Mean dependent var \\
-397.2010
\end{tabular}} \\
\hline \multicolumn{2}{|c|}{$\begin{array}{l}\text { Adjusted R-squared } \\
-0.011720\end{array}$} & \multicolumn{4}{|c|}{$\begin{array}{l}\text { S.D. dependent var } \\
8042.210\end{array}$} \\
\hline \multicolumn{2}{|c|}{$\begin{array}{l}\text { S.E. of regression } \\
8089.201\end{array}$} & \multicolumn{3}{|c|}{$\begin{array}{l}\text { Akaikr info crit } \\
20.84776\end{array}$} & \\
\hline \multicolumn{2}{|c|}{$\begin{array}{l}\text { Sum squared resid } \\
3.85 \mathrm{E}+10\end{array}$} & \multicolumn{3}{|c|}{$\begin{array}{l}\text { Schwarz criterion } \\
20.90661\end{array}$} & \\
\hline \multicolumn{2}{|c|}{ Log likelihood -6215.056} & \multicolumn{3}{|c|}{$\begin{array}{l}\text { Hannan-Quin crit. } \\
20.87067\end{array}$} & \\
\hline \multicolumn{2}{|c|}{$\begin{array}{l}\text { Durbin-Watson stat } \\
2.008845\end{array}$} & & & & \\
\hline
\end{tabular}


- Considering that industry is $75 \%$ efficient, through EViews statistical program we have obtained following results:

\begin{tabular}{|l|l|l|l|l|}
\hline \multicolumn{5}{|l|}{ Included observations: 597} \\
\hline Variable & Coefficient & Std. Error & t-Statistics & Prob. \\
\hline NCOMP & -208.7840 & 1527.882 & -0.136649 & 0.8914 \\
\hline EF & 168.9993 & 4156.546 & 0.040659 & 0.9567 \\
\hline EX & -133.8648 & 3458.070 & -0.038711 & 0.9691 \\
\hline ADV & -0.003367 & 0.062715 & -0.053682 & 0.9572 \\
\hline CR & -9.110440 & 117.6214 & -0.054351 & 0.9567 \\
\hline KI & 0.000175 & 0.003458 & 0.050658 & 0.9596 \\
\hline MS & 139.9555 & 742.2130 & 0.188565 & 0.8505 \\
\hline RD & 0.036909 & 0.325572 & 0.113368 & 0.9098 \\
\hline $\begin{array}{l}\text { R-sqaured } \\
\text {.000163 }\end{array}$ & $\begin{array}{l}\text { Mean dependent var } \\
-397.2010\end{array}$ \\
\hline $\begin{array}{l}\text { Adjusted R-squared } \\
\text {-0.011720 }\end{array}$ & $\begin{array}{l}\text { S.D. dependent var } \\
8042.210\end{array}$ \\
\hline $\begin{array}{l}\text { S.E. of regression } \\
8089.201\end{array}$ & $\begin{array}{l}\text { Akaikr info crit } \\
20.84776\end{array}$ \\
\hline $\begin{array}{l}\text { Sum squared resid } \\
\text { 3.85E+10 }\end{array}$ \\
\hline $\begin{array}{l}\text { Log likelihood } \\
-6215.056\end{array}$ \\
\hline $\begin{array}{l}\text { Durbin-Watson stat } \\
\text { 2.008864 }\end{array}$ \\
\hline
\end{tabular}

- Considering that industry is 95\% efficient, through EViews statistical program we have obtained following results:

\begin{tabular}{|l|l|l|l|l|}
\hline \multicolumn{5}{|l|}{ Included observations: 597} \\
\hline Variable & Coefficient & Std. Error & t-Statistics & Prob. \\
\hline NCOMP & -213.3835 & 2341.393 & -0.091135 & 0.9274 \\
\hline EF & 51.29109 & 4721.190 & 0.010864 & 0.9913 \\
\hline EX & -43.68912 & 4605.107 & -0.009487 & 0.9924 \\
\hline ADV & -0.003370 & 0.062715 & -0.053741 & 0.9572 \\
\hline CR & -8.886193 & 167.6666 & -0.52999 & 0.9578 \\
\hline KI & 0.000175 & 0.003458 & 0.050747 & 0.9595 \\
\hline MS & 135.3867 & 745.2587 & 0.181664 & 0.8559 \\
\hline RD & 0.036769 & 0.325572 & 0.112935 & 0.9101 \\
\hline $\begin{array}{l}\text { R-sqaured } \\
\text { 0.000147 }\end{array}$ & $\begin{array}{l}\text { Mean dependent var } \\
-397.2010\end{array}$ \\
\hline $\begin{array}{l}\text { Adjusted R-squared } \\
\text {-0.011736 }\end{array}$ \\
$\begin{array}{l}\text { S.E. of regression } \\
\text { 8089.264 }\end{array}$ \\
\hline $\begin{array}{l}\text { Sum squared resid } \\
\text { 3.85E+10 }\end{array}$ & $\begin{array}{l}\text { S.D. dependent var } \\
8042.210\end{array}$ \\
\hline
\end{tabular}


N. Mujić, A. Omerbegović Arapović \& E. Cero - Competitiveness of the Oil Market and ...

\begin{tabular}{|l|l|}
\hline Log likelihood & Hannan-Quin crit. \\
-6215.060 & 20.87069 \\
\hline Durbin-Watson stat & \\
2.008845 & \\
\hline
\end{tabular}

Following the described model below are the results for Logistics service industry sector considering 50\% efficiency of industry, $75 \%$ efficiency of industry and $95 \%$ efficiency of industry:

- Considering that Logistics service industry is 50\% efficient, through EViews statistical program we have obtained following results:

\begin{tabular}{|c|c|c|c|c|c|}
\hline \multicolumn{6}{|c|}{ Included observations: 69} \\
\hline Variable & Coefficient & \multicolumn{2}{|c|}{ Std. Error } & t-Statistics & Prob. \\
\hline NCOMP & 3.235876 & \multicolumn{2}{|c|}{2.579968} & 1.25431 & 0.0016 \\
\hline $\mathrm{EF}$ & 34.22194 & \multicolumn{2}{|c|}{8.968699} & 3.815708 & 0.0003 \\
\hline REC & 2.482116 & \multicolumn{2}{|c|}{4.580257} & 0.541916 & 0.5898 \\
\hline$\overline{\mathrm{ADV}}$ & -0.003370 & \multicolumn{2}{|c|}{0.062715} & -0.053741 & 0.9572 \\
\hline $\mathrm{CR}$ & 0.865397 & \multicolumn{2}{|c|}{0.205135} & 4.21867 & 0.0001 \\
\hline KI & -0.178354 & \multicolumn{2}{|c|}{0.009857} & -18.09481 & 0.0002 \\
\hline MS & 2.725765 & \multicolumn{2}{|c|}{0.692798} & 1.54231 & 0.2145 \\
\hline $\mathrm{RD}$ & -0.370048 & \multicolumn{2}{|c|}{0.126474} & -2.925875 & 0.0048 \\
\hline \multicolumn{2}{|c|}{ R-sqaured } & 0.993361 & \multicolumn{3}{|c|}{$\begin{array}{l}\text { Mean dependent var } \\
-9.608696\end{array}$} \\
\hline \multicolumn{3}{|c|}{ Adjusted R-squared } & \multicolumn{3}{|c|}{$\begin{array}{l}\text { S.D. dependent var } \\
114.2687\end{array}$} \\
\hline \multicolumn{3}{|c|}{$\begin{array}{l}\text { S.E. of regression } \\
9.750817\end{array}$} & \multicolumn{3}{|c|}{$\begin{array}{l}\text { Akaikr info crit } \\
7.488506\end{array}$} \\
\hline \multicolumn{3}{|c|}{$\begin{array}{l}\text { Sum squared resid } \\
5894.863\end{array}$} & \multicolumn{2}{|c|}{ Schwarz criterion } & $7 \cdot 715154$ \\
\hline \multicolumn{3}{|c|}{$\begin{array}{l}\text { Log likelihood } \\
-251.3534\end{array}$} & \multicolumn{3}{|c|}{$\begin{array}{l}\text { Hannan-Quin crit. } \\
7.578425\end{array}$} \\
\hline \multicolumn{3}{|c|}{$\begin{array}{l}\text { Durbin-Watson stat } \\
1.890695\end{array}$} & & & \\
\hline
\end{tabular}

- Considering that Logistics service industry is $75 \%$ efficient, through EViews statistical program we have obtained following results:

\begin{tabular}{|l|l|l|l|l|}
\hline \multicolumn{5}{|l|}{ Included observations: 69 } \\
\hline Variable & Coefficient & Std. Error & t-Statistics & Prob. \\
\hline NCOMP & 2.772982 & 2.617618 & 1.059353 & 0.2935 \\
\hline EF & 29.28805 & 7.547303 & 3.879803 & 0.0003 \\
\hline REC & 6.289283 & 4.809602 & 1.307651 & 0.1958 \\
\hline ADV & -0.180987 & 0.053736 & -3.368086 & 0.0013 \\
\hline CR & 0.878552 & 0.406935 & 6.21853 & 0.0023 \\
\hline KI & -0.178024 & 0.009839 & -18.09389 & 0.0000 \\
\hline MS & 2.736570 & 0.686508 & 3.986216 & 0.0002 \\
\hline RD & -0.367272 & 0.125893 & -2.917340 & 0.0049 \\
\hline
\end{tabular}




\begin{tabular}{|l|l|}
\hline R-sqaured & Mean dependent var \\
0.993403 & -9.608696 \\
\hline Adjusted R-squared & S.D. dependent var \\
0.992765 & 114.2687 \\
\hline S.E. of regression & Akaikr info crit \\
9.719558 & 7.4882084 \\
\hline Sum squared resid & Schwarz criterion \\
5857.128 & 7.708732 \\
\hline Log likelihood $\quad-251.1319$ & Hannan-Quin crit. \\
& 7.57003 \\
\hline Durbin-Watson stat & \\
1.876835 & \\
\hline
\end{tabular}

- Considering that Logistics service industry is 95\% efficient, through EViews statistical program author has obtained following results:

\begin{tabular}{|l|l|l|l|l|}
\hline Included observations: 69 \\
\hline Variable & Coefficient & \multicolumn{4}{l|}{ Std. Error } & t-Statistics & Prob. \\
\hline NCOMP & 2.772982 & 2.617618 & 1.059353 & 0.2935 \\
\hline EF & 25.93942 & 6.668215 & 3.8900009 & 0.0002 \\
\hline REC & 8.521386 & 5.03827 & 1.693161 & 0.0954 \\
\hline ADV & -0.182823 & 0.053906 & -3.391533 & 0.0012 \\
\hline CR & 0.978565 & 0.689201 & 6.95113 & 0.0031 \\
\hline KI & -0.177983 & 0.009835 & -18.09718 & 0.0000 \\
\hline MS & 2.759686 & 0.682664 & 4.04524 & 0.0001 \\
\hline RD & -0.364606 & 0.125706 & -2.900463 & 0.0051 \\
\hline R-sqaured \\
0.993403
\end{tabular}

\section{Interpretation of results and conclusions}

This study carries out different tests explaining the relationship between profitability and market structure of Oil industry and Logistics service industry in Federation of Bosnia and Herzegovina.

Using the information provided by Business Intelligence System (BIS) for the period 2014-2019, the study obtains profitability, concentration and market share values for two sectors of activity, Oil sector and Logistics service sector. 
These results are the basis for testing different hypotheses explaining profitability in the generic framework. Thus, the price cost margin of each firm is explained by the concentration of the market in which it operates, by its markets share, by its levels of efficiency as well as a set of control variables (research and development, advertising expenditure, capital intensity, etc.)

The results obtained about the market structure in which the Oil firms operate allow us to conclude that even though values of HHI calculated fit into Medium concentrated type of market, more important observation is the fact that just up to ten firms in the whole industry have percentage of market share above $1 \%$, and one has the largest share in industry of $30-40 \%$ market share which is more than double of every other firm in the industry.

So, even if the market ostensibly looks sort-of competitive, the market share of each firm calculated shows us that there is one leading company in the industry over the observed period of time and all other things constant, market share is continuously rising for this particular firm.

The results obtained through comparing profitability of Oil industry sector and Logistics service sector allow us to have a clear image of huge differences in profitability of Oil sector over the Logistics service sector. Also the Oil sector profitability multiplies two times from 2014 until 2018 what we can see from the profitability curve facing upwards. On the other hand, from obtained results we see the decreasing trend in profitability of Logistics service sectors where profitability of industry in 2018 multiple times lower than in 2018.

Based on the data, there is a huge gap between two curves which represent the profitability of Oil sector over the Logistics service sector.

Based on previous data research and observation, we can state that Oil industry in FB\&H is surely enjoying the profits above the norm comparing to other industries in country.

Through Unit root test we confirmed that the series are stationary and that other series are stationary. $\mathrm{ADF}$ is greater than test value and critical at $1 \%$. So we can continue with the results from the Linear regression model.

The results obtained through regression model of profitability testing main financial variables, gross profit margins and the market size of the company allow us to conclude:

\section{Oil industry}

Testing different levels of efficiency in Oil industry through Simple linear regression model we have obtained similar R squared results being low as $0.1 \%$. Here we can conclude that independent variables do not significantly affect the profitability of Oil industry.

Going through the depended variables we can conclude that there is no significant evidence that independent variables such as R\&D expenditure, Capital intensity, conditions of the market and advertising expenditure positively affect the profitability of the Oil industry in Federation of Bosnia and Herzegovina. When included in the same model both concentration and market share, concentration HHI gets, in general inconclusive and non-significant.

On the other hand there is statistically significant evidence that there is positive correlation between the profitability of the industry and the market share in which the firm operates in all years studied (2014-2019) It is important to point out that the market share maintains its sign and its significance. This result shows the importance of market power in explaining profitability. Berger in his study (Berger, 1995), indicate that the coefficient of dependent variable Market share maintains its sign and significance when efficiency is introduced into the regression, suggests that in earlier regressions where this effect is not introduced, the variable MS should not be interpreted as a proxy of efficiency, but as capturing the effect of factors 
other than efficiency. Thus, the results show the inappropriateness of using the market share as a proxy variable for efficiency.

When results like this, we can say that Oil industry comparing to Logistics service industry is annoying the profits above the norm and is competing in Oligopolistic type of market structure.

From the above results the hypothesis of profitability of Oil industry in Federation of Bosnia and Herzegovina is not rejected, since there is a positive relationship between market share and profitability of the industry. Another result is the importance of efficiency and market power being the explanatory variables of profitability, concluding that there is significant evidence that there is positive correlation between the profitability and efficiency of the industry.

\section{Logistics and service industry}

Testing different levels of efficiency in Oil industry through Simple linear regression model, we obtained similar R squared results being high as $99 \%$. Here we can conclude that independent variables significantly affect the profitability of Logistics service industry.

From the results obtained in the Logistics service industry we can conclude that there is significant evidence that there is positive relationship between the profitability and the market share of the industry, but it is important to state that there is also significant evidence that there is a positive relationship between the concentration of the industry and the profitability.

There is no significant evidence that there is positive relationship between the variables of R\&D expenditure, Advertising expenditure and Capital intensity and the profitability of the Logistics service sector.

From the above results the hypothesis of profitability of Logistics service industry in Federation of Bosnia and Herzegovina is not rejected, since there is a positive relationship between market share and profitability of the industry. Another result is the importance of efficiency and market power being the explanatory variables of profitability, concluding that there is significant evidence that there is positive correlation between the profitability and efficiency of the industry.

\section{Acknowledgements}

This research did not receive any specific grant from funding agencies in the public commercial, or not-for-profit sectors.

The authors declare no competing interests.

\section{References}

Bain, J. S. (1951). Relation of profit rate to industry concentration: American manufacturing, 1936-1940. The Quarterly Journal of Economics, 51-59.

Begović, B., Bukvić, R., Mijatović, B., Paunović, M., Sepi, R., \& Hiber, D. (2002). Antimonopolska politika u SR Jugoslaviji [Antitrust policy in SR Yugoslavia]. Beograd: Centar za liberalno-demokratske studije.

Berger, A. N. (1995). The profit-structure relationship in banking: Test of market-power and efficientstructure hypotheses. Journal of Money, Credit and Banking, 27(2), 404-431. 
N. Mujić, A. Omerbegović Arapović \& E. Cero - Competitiveness of the Oil Market and ...

Demsetz, H. (1973). Industry structure, market rivalry, and public policy. Journal of Law and Economics, 16(1), 1-9.

Granić, G., Zeljko, M., Moranjkic, I., Martinez, J., Olano, M., \& Juric, Z. (2008). Studija energetskog sektora $B I H$ [Study of energy sector of B\&H]. ESSBIH.

Gumbau, M., \& Maudos, M. G. (2000). Profitability, market structure and efficiency: An application to the Spanish industry. Valencia: Instituto Valenciano de Investigaciones Económicas.

Lipczynski, J., \& Wilson, J. O. (2001). Industrial organization: An analysis of competitive markets. Financial Times, 110.

Mazon, C. (1993). Is profitability related to market share? Documento de trabajo 9327, Servicio de Estudios.

Muller, D. C. (1977). The persistence of profits above the norm. Economica, 44(176), 369-80.

... (2019). On the mark. The Economist, 61 (6 April 2019).

Schmalensee, R. (1987). Collusion versus differential efficiency: Testing alternative hypotheses. Journal of Industrial Economics, 35(4), 399-425.

Shepard, W. G. (1982). Economies of scale and monopoly profits. In: Industrial Organization, Antitrust, and Public Policy. Boston: Kluwer Nijhoff.

Sousa, M. (2015). Does the market structure matter for firms' profitability? - Master Thesis. Lisbon School of Economics and Management. 